Dinamika Sosial Budaya, Vol 22, No. 1, Juni 2020, pp 45-53

p-ISSN: 1410-9859\& e-ISSN: 2580-8524

http://journals.usm.ac.id/index.php/jdsb

\title{
STRATEGI MENINGKATKAN LOYALITAS DENGAN PELAYANAN PRIMA, CUSTOMER RELATIONSHIP MANAGEMENT DAN KEPUASAN PELANGGAN
}

(Studi Pada Rumah Batik Danar Hadi Semarang)

\author{
Iwan Prasetyo. SE., MM \\ Program Studi Manajemen Fakultas Ekonomi Universitas Semarang \\ Iwan.usm@yahoo.ac.id \\ Tri Endang Yani. SE.,Msi \\ Program Studi Manajemen Fakultas Ekonomi Universitas Semarang \\ triendangyani_usm@yahoo.com
}

\begin{abstract}
Abstraksi
Adapun tujuan pada penelitian ini untuk mengetahui adanya keterkaitan antara variabel pelayanan prima, customer relationship management dan kepuasan pelanggan terhadap loyalitas pelanggan pada Rumah Baatik Danar Hadi Semarang. Populasi penelitian ini adalah pelanggan pada Rumah dengan sample sebesar 100 pelanggan, dengan metode penentuan sample menggunakan purposive sampling dengan alat analisis regresi linier berganda. Dari hasil penelitian yang telah dilakukan didapatkan hasil 1) Terdapat pengaruh positif 0,184 dan sig 0,041 variabel pelayanan prima terhadap loyalitas pelanggan 2) Terdapat pengaruh positif 0,531 sig 0,000 variabel customer relationship management terhadap loyalitas pelanggan 3) Terdapat pengaruh positif 0,214 sig 0,40 variabel kepuasan pelanggan terhadap loyalitas pelanggan. Dari hasil uji koefisien determinasi didapatkan nilai Adjust $R$ square sebesar 0,742 berarti secara keseluruhan loyalitas dipengaruhi oleh variabel pelayanan prima, customer relationship management dan kepuasan kerja sebesar $74,2 \%$.

Kata Kunci : Pelayanan Prima, Customer Relationship Management, Kepuasan Pelanggan, Loyalitas Pelanggan,
\end{abstract}

\begin{abstract}
The purpose of this study was to determine the relationship between excellent service variables, customer relationship management and customer satisfaction with customer loyalty at Rumah Baatik Danar Hadi Semarang. The population of this study is customers at home with a sample of 100 customers, with the method of determining the sample using purposive sampling with multiple linear regression analysis tools. From the results of the research that has been done, the results obtained 1) There is a positive influence of 0.184 and sig of 0.041 excellent service variables on customer loyalty 2) There is a positive influence of 0.531 sig 0,000 customer relationship management variables on customer loyalty 3) There is a positive influence of 0.214 sig 0.40 of satisfaction variables customer loyalty. From the coefficient of determination test results obtained Adjust $R$ square value of 0.742 means that overall loyalty is influenced by excellent service variables, customer relationship management and job satisfaction by $74.2 \%$.
\end{abstract}

Keywords: Excellent Service, Customer Relationship Management, Customer Satisfaction, Customer Loyalty 


\section{PENDAHULUAN}

Standart kualitas pelayanan merupakan salah satu upaya yang dilakukan oleh sebuah perusahaan untuk menghadapi persaingan dalam dunia bisnis saat ini. Pesatya perkembangan tehnologi saat ini dalam bidang fashion batik khususnya menyebabkan kemudahan konsumen untuk memilihi secara bebas, oleh karna itu kesempatan perusahaan untuk mendapatka loyalitas customer menjadi sangat kecil. Dengan adanya persaingan antara perusahaan yang sangat ketat hal menuntut perusahaan untuk lebih kreatif dan inovatif. Selain dalam bidang strategi pemasaran perusahaan juga harus membuat standart mengenai pelayanan yang diberikan kepada customernya. Dimana diharapkan dengan adanya standart pelayanan maka tingkat pelayanan kepada customer bisa lebih baik, sehingga akan tercipta loyalitas pelanggan.

Loyalitas menurut Hurriyati (2008) Adanya keterkaitan komitmen yang dimiliki antara pelanggan dengan perusahaan untuk kembali melakukan pembelian di masa yang akan datang. Griffin (2008), loyalitas customer merupakan sebuah perilaku yang ditunjukan customer dengan pembelian rutin, berdasarkan pada unit dalam pengambilan keputusan, Thaichon (2014) merupakan konsep penting dan kritis dalam manajemen pelayanan. Dari beberapa teori diatas dapat ditarik kesimpulan jika loyalitas merupakan sikap yang positif yang diberikan cutomer kepada perusahaan terhadapa produk ataupun jasa sehingga customer tersebut akan datang untuk membeli ataupun memakai produk dan jasa dari perusahaan tersebut.

Dimana untuk meningkatkan loyalitas pelanggan dapat dilakukan dengan memberikan kualitas pelayanan yang baik terhadap customer. Lee and Moghavemi (2015) menyebutkan jika kualitas pelayanan merupakan hasil pelayanan dan proses pelayanan yang diberikan oleh perusahaan terhadap customernya. Tidak hanya kualitas pelayanan saja yang diperhatikan tetapi cara pelayanan kepada pelangga juga harus prima. Dengan adanya pelayanan yang prima dapat menjadikan pembeda dengan perusahaan lain mengenai pelayanan yang diberikan kepada customernya, Ruslan (2005) Pelayanan Prima berberkaitan dengan jasa pelayanan yang dilaksanakan oleh perusahaan dalam upaya untuk memberikan rasa kepuasan dan menumbuhkan kepercayaan pihak pelanggan kepada perusahaan. Dimana Hubungan pelayanan prima terhadap loyalitas customer sangat penting bagi perusahaan. Dengan memberikan pelayanan prima kepada customer berarti perusahaan sudah berusaha memberikan kualitas pelayanan dengan baik, diharapkan dengan pelayanan yang baik maka customer tersebut akan loyal terhadap perusahaan. Berdasarkan study yang telah dilakukan oleh Basuki Cahyono (2013) menunjukan jika pengaruh yang signifikan terhadap loyalitas pelanggan.

Selain itu untuk mempertahankan loyalitas pelanggan diperlukan usaha untuk menjaga hubungan baik antara pelanggan lama atau dikenal dengan customer relationship management. Kotler \& Amstrong (2008) proses membangun dan menjaga hubungan terhadap customer yang menguntungkan dengan menghantarkan nilai dan kepuasan pelanggan, Lupiyoadi (2009) Menarik dan mempertahankan hubungan pelanggan melalui meningkatkan hubungan. Alma (2010) Suatu proses mendapatkan, mempertahankan, meningkatkan hubungan yang menguntungkan, Lovelock \& Wirtz (2011) suatu sistem implementasi untuk meningkatkan, Kotler \& Armstrong (2012) proses maintanance profit dari customer untuk menciptakan nilai dan kepuasan, Kotler dan Keller (2009) proses mengelola informasi rinci tentang pelanggan perorangan untuk memaksimalkan loyalitas. Dengan adanya pengelolaan customer relationship management dengan baik, dimana customer relationship menagement ini berbasis pengelolaan terhadap customer dengan membangun komunikasi secara insten yaitu pendekatan secara personal diharapkan dapat meningkatkan loyalitas customer. Dari beberapa penelitian yang telah dilakukan oleh Halimah (2015) mengenai pengaruh customer relationship management serta penelitian Christian Victor (2015) memiliki hasil yang sama yaitu customer relationship management perpengaruh signifikan terhadap kepuasan dan loyalitas 
Dalam persaingan bisnis saat ini penilai positif yang diberikan customer kepada perusahaan sangatlah, hal tersebut menandakan jika customer yang bersangkutan merasa puas atas apa yang mereka harapkan dari perusahaan dapat tercapai. Menurut Kotler dan Keller (2009) perasaan pelanggan yang dihasilkan dari membandingkan kinerja yang dipersepsikan dengan ekspektasi pelanggan, mengevaluasi akan sesuai suatu produk atau jasa dengan yang diharapkan oleh konsumen Schiffman dan Kanuk (2007). Memberi kepuasan kepada konsumen adalah hal yang sangat penting bagi perusahaan. Karena kepuasan yang tinggi akan berdampak pada loyalitas konsumen menurut Tjiptono (2008). Dari hasil penelitian yang telah dilakukan oleh David Harianto (2016) mengenai kepuasan konsumen sebagai variabel intervening konsumen Kedai Deja-Vu dan Novan Haryono (2014) menyatakan bahwa kepuasan kerja berpengaruh secara signifikan terhadap kelpuasan pelanggan.

Fenomena bisnis yang terjadi saat ini pada PT Danar Hadi sedang mengalami penurunan loyalitas pelanggan, dimana penurunan dapat dilihat dari penggunaan member Batik Danar Hadi yang menurun dari tahun 2017 sampai tahun 2018. Dari penurunan jumlah pengguna member akan berdampak pada perolehan pendapatan pengurangan dari penjualan sebesar 104 pengguna member baik dari kategori member reguler, silver ataupun gold dengan nilai value kurang lebih sebesar Rp 876.618.191 Dari penuruna pengguna member tersebut dapat ditarik kesimpulan jika masalah yang terjadi pada Rumah Batik Danar Hadi semarang saat ini mengalami penurunan loyalitas customer member dari tahun 2017 sampai 2018. Dari fenomena diatas peneliti sangat tertarik untuk melakukan penelitian mengenai sebab penurunan loyalitas customer pada Rumah Batik Danar Hadi Semarang. Berdasarkan latar belakang yang telah diuraikan diatas maka peneliti tertarik mengambil Judul Penelitian Strategi Meningkatkan Loyalitas Dengan Pelayanan Prima, Customer Relationship Management Dan Kepuasan Pelanggan “ Studi Pada Rumah Batik Danar Hadi Semarang “

\section{TINJAUAN PUSTAKA}

\section{Loyalitas Pelanggan}

Menurut Lupiyoadi (2009) prefensi customer terhadap orang lain dan pembelian secara actual di lain waktu, Rasyid (2017) suatu kesetiaan customer kepada suatu produk atau perusahaan dan dengan senang hati akan berbagi dengan orang lain tentang pengalaman dan pengetahuan mereka serta adanya urasa bangga tersendiri mereka menggunakan produk atau jasa dari perusahaan itu. Merupakan hubungan yang kuat antara customer dengan perusahaan Chang (2013), suatu konsep penting dalam sebuah manajemen pelayanan Thaicon (2014), Arshad (2016) komitmen customer terhadap suatu produk, sejalan dengan itu jika customer sudah merasa tidak puas maka mereka akan mencari produk pengganti Amin (2011) Kaur (2012). Berdasarkan beberapa teori yang dikemukanan bisa disimpulkan jika loyalitas customer merupakan suatu sikap baik yang diberikan kepada perusahaan atas dasar pelayanan yang diberikan perusahaan sehingga akan menimbulkan rasa setia terhadap perusahaan dan akan memberikan kesan positif perusahaan kepada orang lain

\section{Pelayanan Prima}

Pelayanan prima berarti pelayanan terbaik yang diberikan oleh seorang karyawan kepada customernya, pelayanan ini melebihi standart pelayanan atau standart service yang telah ditentukan oleh perusahaan. Pada pelayanan prima ini dapat diciptakan dengan sendiri nya oleh karyaan pada sebuah perusahaan tergantung motivasi dan karateristik setiap karyawan. Menurut Daryanto dan Ismanto (2014) nilai tambah yang diberikan dalam proses pelayanan, Maddy (2009) pelayanan yang memenuhi standart kualitas, Dari beberapa pengertian diatas dapat diatarik kesimpulan jika pelayanan prima merupakan suatu proses pelayanan yang diberikan kepada customer dengan didasari rasa kepedulian untuk membantu seseorang secara tulus sehingga akan menimbulkan rasa puas dari customer. 
Dinamika Sosial Budaya, Vol 22, No. 1, Juni 2020, pp 45-53

p-ISSN: 1410-9859\& e-ISSN: 2580-8524

http://journals.usm.ac.id/index.php/jdsb

\section{Customer Relationship Management (CRM)}

Customer Relationship management adalah proses pengelolaan data customer secara rinci untuk memaksimalkan kesetiaan pelanggan Kotler dan Keller (2007), Alma (2010) Suatu proses mendapatkan, mempertahankan, meningkatkan hubungan yang menguntungkan, Lovelock \& Wirtz (2011) suatu sistem implementasi untuk meningkatkan, Kotler \& Armstrong (2012) proses maintanance profit dari customer untuk menciptakan nilai dan kepuasan, Kotler dan Keller (2009) proses mengelola informasi rinci tentang pelanggan perorangan untuk memaksimalkan loyalitas.

\section{Kepuasan Pelanggan}

Kepuasan keseluruhan (overall satisfaction) didefinisikan sebagai pernyataan efektif tentang reaksi emosional terhadap pengalaman atas produk atau layanan yang dipengaruhi oleh kepuasan konsumen terhadap produk tersebut (attribute satisfaction) dan informasi yang digunakan untuk memilih produk (information satisfaction). Kepuasan palanggan berhubungan erat dengan loyalitas pelanggan, dimana pelanggan yang terpuaskan akan menjadi pelanggan yang loyal. Kepuasan pelanggan akan tercapai apabila harapan sesuai dengan kenyataan yang diterima. Kepuasan pelanggan tinggi apabila nilai yang dirasakan melebihi harapan pelanggan. Penerimaan produk dengan kualitas yang lebih tinggi akan mendapatkan tingkat kepuasan yang lebih tinggi daripada penerimaan produk dengan kualitas yang lebih rendah

\section{METODE PENELITIAN}

Jenis penelitian yang telah dilakukan merupakan penelitian kuantitatif, dimana penelitia ini berdasarkan perhitungan dan pengambilan keputusan akan kesimpulan berdasarkan analisis statistik (Arikunto, 2010). Peubah yang diamati menurut (Sugiono, 2008) menyatakan bahwa variabel adalah Konstruk atau sifat yang akan dipelajari. Sedangkan menurut (Sugiono, 2008). Variabel adalah atribut seseorang atau objek yang mempunyai variasi antara satu dengan yang lainnya. Pada penelitian ini menggunakan tiga variabel penelitian antara lain
Variabel Independen atau variabel bebas (X) adalah variabel yang mempengaruhi variabel dependen, dimana pengaruh yang dihasilkan bisa berpengaruh positif ataupun negatif. Variabel independen pada penelitian ini adalah sebagai berikut :

1. Pelayanan Prima (Barata, 2011) merupakan suatu proses pelayanan yang diberikan kepada customer dengan didasari rasa kepedulian untuk membantu seseorang secara tulus sehingga akan menimbulkan rasa puas dari customer

2. Customer relationship management menurut (Sheth dan Shainesh, 2002) merupakan Customer relationship management merupakan suatu proses pengelolaan customer secara individual dan terperinci guna untuk mencapai kesetiaan customer terhadap perusahaan.

3. Kepuasan Pelanggan (Tjiptono, 2008) merupakan Perasaan pelanggan yang dihasilkan dari membandingkan kinerja yang dipersepsikan dengan ekspektasi pelanggan, mengevaluasi akan sesuai suatu produk atau jasa dengan yang diharapkan oleh konsumen.

Variabel Dependen atau variabel tetap (Y) adalah variabel yang dipengaruhi oleh variabel independen, dimana variabel dependen ini merupakan pokok dari permasalahan dalam penelitian. Dalam penelitian ini variabel dependen nya adalah loyalitas pelanggan (Griffin 1995) didefinisikan sebagai suatu sikap kesetiaan yang diberikan kepada perusahaan atas dasar pelayanan yang diberikan perusahaan sehingga akan menimbulkan pembelian berulang di lain kesempatan dan akan memberikan kesan positif perusahaan kepada orang lain

Lokasi dilakukan penelitian pada Rumah Batik Danar Hadi Semarang. Data yang digunakan pada penelitian ini adalah data primer yang didapatkan dari pengisian kuesioner yang dibagikan dan disebar kepada member Danar Hadi. Unit sampel diambil 100 responden dengan metode penentuan smple menggunakan Purposive sampling dimana pengambilan secara acak. Dalam hal ini unit sampelnya adalah member Batik Danar Hadi. 
Dinamika Sosial Budaya, Vol 22, No. 1, Juni 2020, pp 45-53

p-ISSN: 1410-9859\& e-ISSN: 2580-8524

http://journals.usm.ac.id/index.php/jdsb

\section{HASIL DAN PEMBAHASAN}

\section{Uji Validitas}

Berdasarkan tabel hasil uji validitas yang telah dilakukan sebelumnya didapatkan nilai bahwa semua item indikator pada setiap variabel penelitian Pelayanan Prima $\left(\mathrm{X}_{1}\right)$, Customer Relationship Management $\left(\mathrm{X}_{2}\right)$, Kepuasan Pelanggan $\left(\mathrm{X}_{3}\right)$ dan Loyalitas pelanggan (Y) dinyatakan valid karena hasil dari korelasi antara hasil jawaban responden setiap item indikator dengan skor total di dapat hasil yang signifikan, yaitu nilai $r$ hitung $>r$ tabel dengan taraf signifikan sebesar $5 \%$

\section{Uji Reliabilitas}

\begin{tabular}{|c|l|c|c|}
\hline No & Variabel & $\begin{array}{c}\text { Cronba } \\
\text { ch } \\
\text { Alpha }\end{array}$ & $\begin{array}{c}\text { Keteranga } \\
\text { n }\end{array}$ \\
\hline 1 & Pelayanan Prima & 0,809 & Realibel \\
\hline 2 & CRM & 0,929 & Realibel \\
\hline 3 & $\begin{array}{l}\text { Kepuasan } \\
\text { Pelanggan }\end{array}$ & 0724 & Realibel \\
\hline 3 & $\begin{array}{l}\text { Loyalitas } \\
\text { Pelanggan }\end{array}$ & 0,804 & Realibel \\
\hline
\end{tabular}

Dari hasil uji realibel diatas variable pelayanan prima, customer relationship management dan loyalitas pelanggan memiliki nilai Cronbach Alpha semua > dari pada 0,70 sehingga dapat disimpulkan bahwa semua indikator realibel atau handal untuk digunakan sebagai alat ukur variable.

\section{Analisis Regresi Linier Berganda}

Analisis regresi linier berganda digunakan untuk melihat pengaruh antara variable Pelayanan Prima, Customer Relationship Management, Kepuassan Pelanggan tehadap Loyalitas Pelanggan. Hasil analisis regresi berganda dengan menggunakan program SPSS adalah sebagai berikut :

\begin{tabular}{|c|c|c|c|c|c|c|}
\hline \multirow{2}{*}{\multicolumn{2}{|c|}{ Model }} & \multicolumn{2}{|c|}{$\begin{array}{l}\text { Unstandardize } \\
\text { d Coefficients }\end{array}$} & \multirow{2}{*}{$\begin{array}{c}\begin{array}{c}\text { Standardize } \\
\mathrm{d} \\
\text { Coefficients }\end{array} \\
\text { Beta }\end{array}$} & \multirow[b]{2}{*}{$\mathrm{T}$} & \multirow[b]{2}{*}{ Sig. } \\
\hline & & B & $\begin{array}{l}\text { Std. } \\
\text { Error }\end{array}$ & & & \\
\hline 1 & $\begin{array}{l}\text { (Const } \\
\text { ) }\end{array}$ & 2,213 & 1,331 & & 1,662 & , 100 \\
\hline & $\mathrm{X} 1$ & , 151 & ,073 & , 184 & 2,070 & ,041 \\
\hline & $\mathrm{X} 2$ & ,335 &, 055 & ,531 & 6,045 & ,000 \\
\hline & X3 & ,196 & ,095 & ,214 & 2,079 & ,040 \\
\hline
\end{tabular}

Berdasarkan hasil analisis regresi linier berganda yang didapat maka dibuat persamaan liniear berganda sebagai berikut :

$$
\text { LP = 0,184 (PL) + 0,531 (CRM) + 0,214 (KP) }
$$

Persamaan linier berganda yang dapat diartikan :

1. Dari hasil koefisien regresi didapatkan nilai positif sebesar 0,184 untuk variabel pelayanan prima. Sehingga dapat disimpulkan dengan ditingkatkannya variabel pelayanan prima maka variabel loyalitas pelanggan akan mengalami peningkatan dengan asumsi variabel lain akan tetap.

2. Dari hasil koefisien regresi didapatkan nilai positif sebesar 0,531 untuk variabel customer relatinship management. Sehingga dapat disimpulkan dengan ditingkatkannya variabel customer relatinship management maka variabel loyalitas pelanggan akan mengalami peningkatan dengan asumsi variabel lain akan tetap

3. Dari hasil koefisien regresi didapatkan nilai positif sebesar 0,214 untuk variabel kepuasan pelanggan. Sehingga dapat disimpulkan dengan ditingkatkan nya variabel kepuasan pelanggan maka variabel loyalitas pelanggan akan mengalami peningkatan dengan asumsi variabel lain akan tetap.

\section{Koefisien Determinasi.}

Dari uji koefisien determinasi diperolehnilai Adjust R Square 0,742 yang artinya 74,2\% variabel dari loyalitas pelanggan dipengaruhi oleh variabel bebas Pelayanan Prima, Customer Relationship Management, Kepuasan Pelanggan, sedangkan 
sisanya diterangkan oleh variabel lain yang tidak diteliti oleh peneliti.

\section{Uji Statistik F.}

Berdasarkan tabel diatas $\mathrm{f}$ hitung sebesar 95,841 dan nilai probabilitas signifikan sebesar 0,000 dibawah nilai kritis 0,05 atau $5 \%$. Hal ini berarti bahwa variabel independen berpengaruh terhadap variabel dependen.

\section{Pengujian Hipotesis (Uji Statistik t)}

Pada pengujian ini dilakukan dengan melihat taraf signifikan P-value hasil hitung. Jika taraf signifikan yang dihasilkan dari perhitungan $<0.05$ maka hipotesis diterima, sedangkan jika taraf signifikan hasil hitung > 0,05 maka hipotesis ditolak.

\begin{tabular}{|c|c|c|c|c|c|}
\hline \multirow[t]{2}{*}{ Model } & \multicolumn{2}{|c|}{$\begin{array}{l}\text { Unstandardiz } \\
\text { ed } \\
\text { Coefficients }\end{array}$} & \multirow{2}{*}{$\begin{array}{c}\begin{array}{c}\text { Standardize } \\
\mathrm{d}\end{array} \\
\text { Coefficients }\end{array}$} & \multirow[b]{2}{*}{$\mathrm{T}$} & \multirow[b]{2}{*}{ Sig. } \\
\hline & B & $\begin{array}{l}\text { Std. } \\
\text { Error }\end{array}$ & & & \\
\hline $\begin{array}{c}1 \text { (Const } \\
\text { ) }\end{array}$ & 2,213 & 1,331 & & 1,662 &, 100 \\
\hline $\mathrm{X} 1$ &, 151 & 073 & 184 & 2,070 & 041 \\
\hline $\mathrm{X} 2$ & ,335 & 055 & ,531 & 6,045 & ,000 \\
\hline $\mathrm{X} 3$ & , 196 & 095 & 214 & 2,079 & 040 \\
\hline
\end{tabular}

Hipotesis 1 : Pengaruh Pelayanan Prima Terhadap Loyalitas Pelanggan Pada Rumah Batik Danar Hadi Semarang.

Dari uji statistik t diatas didapatkan nilai signifikansi sebesar 0,041 dimana nilai tersebut lebih kecil 0,05. Yang berarti hipotesis pertama pada penelitian ini yaitu variabel pelayanan prima diterima dan berpengaruh secara signifikan terhadap loyalitas pelanggan.

"Signifikan" berarti bahwa pelayanan prima mempunyai pengaruh yang bermakna/signifikan terhadap loyalitas pelanggan, sehingga dapat disimpulkan bahwa pelayanan prima merupakan penentu adanya loyalitas pelanggan pada Rumah Batik Danar Hadi.

Koefisien beta (koefisien regresi) variabel pelayanan prima adalah 0,184 atau $18,4 \%$. Dimana Koefisien regresi ini merepresentasikan kekuatan pengaruh variabel pelayanan prima terhadap variabel Loyalitas Pelanggan. Arti dari koefisien regresi 18,4\% tersebut adalah jika variabel bebas yang lain dianggap tetap (tidak ada perubahan) dan variabel pelayanan prima ditingkatkan sebesar $1 \%$ dari pada sebelumnya, maka akan diikuti oleh kenaikan variabel loyalitas pelanggan sebesar $18,4 \%$.

\section{Hipotesis 2 : Pengaruh Customer Relationship Management Terhadap Loyalitas Pelanggan Pada Rumah Batik Danar Hadi Semarang.}

Dari uji statistik t diatas didapatkan nilai signifikansi sebesar 0,00 dimana nilai tersebut lebih kecil 0,05. Yang berarti hipotesis kedua pada penelitian ini yaitu variabel customer relationship management diterima dan berpengaruh secara signifikan terhadap loyalitas pelanggan.

"Signifikan" berarti bahwa customer relationship management mempunyai pengaruh yang bermakna / signifikan terhadap loyalitas pelanggan, sehingga dapat disimpulkan bahwa customer relationship manegement merupakan penentu adanya loyalitas pelanggan pada Rumah Batik Danar Hadi.

Koefisien beta (koefisien regresi) variabel customer relationship management adalah 0,531 atau $53,1 \%$. Dimana Koefisien regresi ini merepresentasikan kekuatan pengaruh variabel customer relationship management terhadap variabel Loyalitas Pelanggan. Arti dari koefisien regresi 53,1\% tersebut adalah jika variabel bebas yang lain dianggap tetap (tidak ada perubahan) dan variabel customer relationship management ditingkatkan sebesar $1 \%$ dari pada sebelumnya, maka akan diikuti oleh kenaikan variabel loyalitas pelanggan sebesar 53,1\%.

\section{Hipotesis 3 : Pengaruh Kepuasan Pelanggan Terhadap Loyalitas Pelanggan Pada Rumah Batik Danar Hadi Semarang}

Dari uji statistik t diatas didapatkan nilai signifikansi sebesar 0,04 dimana nilai tersebut lebih kecil 0,05. Yang berarti hipotesis ketiga pada penelitian ini yaitu variabel kepuasan pelanggan diterima dan berpengaruh secara signifikan terhadap loyalitas pelanggan 
"Signifikan" berarti bahwa kepuasan pelanggan mempunyai pengaruh yang bermakna/signifikan terhadap loyalitas pelanggan, sehingga dapat disimpulkan bahwa kepuasan pelanggan merupakan penentu adanya loyalitas pelanggan pada Rumah Batik Danar Hadi.

Koefisien beta (koefisien regresi) variabel kepuasan pelanggan adalah 0,214 atau 21,4 \% . Dimana Koefisien regresi ini merepresentasikan kekuatan pengaruh variabel kepuasan pelanggan terhadap variabel Loyalitas Pelanggan. Arti dari koefisien regresi 21,4\% tersebut adalah jika variabel bebas yang lain dianggap tetap (tidak ada perubahan) dan variabel kepuasan pelanggan ditingkatkan sebesar $1 \%$ dari pada sebelumnya, maka akan diikuti oleh kenaikan variabel loyalitas pelanggan sebesar 21,4\%

\section{Pembahasan}

a. Didapatkan hasil yang positif dan signifikan dari pengujian secara regresi dan uji statistik t pada variabel pelayanan prima. Hal tersebut dapat disimpulkan jika semakin baik variabel pelayanan prima akan semakin baik atau meningkat loyalitas pelanggan. Untuk meningkatkan pelayanan prima perlu dilakukan dengan memberikan pelayanan yang baik kepaa customer, selalu berperiku sopan dan memiliki jiwa menolong kepada customer, selalu memperhatikan penampilan dan lebih aktif lagi dalam pelayanan terhadap customer. Dimana penelitian yang saya lakukan ini sejalan dengan penelitian terdahulu yang dilakukan oleh Basuki Cahyono (2011) Analisa Kekuatan Strategi Pemasaran Melalui Online Marketing, Offline Marketing Dan Service Excellent Terhadap Loyalitas Konsumen PT. Adinata Graha Raya Kaliwungu Dengan Kepuasan Konsumen Sebagai Variabel Intervening didapatkan bahwa pelayanan prima berpengaruh positif dan signifikan terhadap loyalitas pelanggan.

b. Didapatkan hasil yang positif signifikan dari pengujian secara regresi dan uji statistik t pada variabel. Hal tersebut disimpulkan jika variabel customer realtionship management semakin baik maka loyalitas pelanggan menjadi baik.. Dimana penelitian yang saya lakukan ini sejalan dengan penelitian terdahulu yang dilakukan oleh Christian Victor (2015) Pengaruh Customer Relationship Management Dan Kepercayaan Terhadap Kepuasan Serta Dampaknya Terhadap Loyalitas Konsumen Pt. Bank Bca Tbk. Di Manado

c. Didapatkan hasil yang positif dan signifikan dari pengujian secara regresi dan uji statistik t pada variabel kepuasan pelanggan. Hal tersebut dapat disimpulkan jika semakin baik variabel kepuasan pelanggan akan semakin baik atau meningkat loyalitas pelanggan pada Rumah Batik Danar Hadi. Dimana untuk meningkatkan loyalitas dapat dilakukan dengan cara tetap mempertahankan kualitas batik itu sendiri baik dari segi pewarnaan, kualitas bahan, dan mempertahan kan ciri khas desain motif dari batik danar hari, untuk pelayanan terhadap customer lebih awarenes lagi serta lebih agresif dan sabar dalam memberikan pelayanan terhadap customer sehingga tidak atimbul asumsi negatif terhadap perusahaan.

\section{KESIMPULAN}

Dapat ditarik kesimpulan untuk diambil keputusan yang telah dilakukan pada bab sebelum nya sebagai berikut :

a. Variabel pelayanan prima di dapatkan pengaruh secara positif signifikan terhadap veriabel loyalitas pelanggan. Artinya semakin baik pelayanan prima karyawan terhadap pelanggan maka pelanggan akan semakin loyal terhadap Batik Danar Hadi

b. Variabel customer relationship management didapatkan pengaruh positif signifikan terhadap loyalitas pelanggan. Artinya semakin baik etika komunikasi karyawan terhadap pelanggan maka pelanggan akan semakin loyal terhadap Batik Danar Hadi 
c. Variabel kepuasan pelanggan didapatkan pengaruh secara positif signifikan terhadap loyalitas pelanggan. Artinya pelanggan yang semakin puas kepada Batik Danar Hadi maka pelangaan tersebut akan semakin loyal.

\section{Saran}

a. Mengingat hasil dari pengujian pelayanan prima terhadap loyalitas pelanggan menghasilkan nilai positif signifikan. Maka diharapkan Rumah Batik Danar Hadi tetap mempertahankan pelayanan terhadap customer terutama member Batik Danar Hadi sehingga costomer akan loyal terhadap Rumah Batik Danar Hadi.

b. Dari pengujian variabel customer relationship management diatas didapatkan hasil positif signifikan customer realationship management terhadap loyalitas pelanggan. Oleh sebab itu diharapkan Rumah Batik Danar Hadi Semarang harus memiliki inisiatif sendiri melalui customer relationship management store dengan memperbaiki CRM yang sudah ada pada perusahaan, yaitu dengan memberikan pelayanan secara personal kepada pelanggan dan jika diperlukan menjalin kerjasama terhadap instansi yang ada.

c. Dari hasil pengujian kepuasan pelanggan terhadap loyalitas pelanggan pada Rumah Batik Danar Hadi di dapatkan nilai positif signifikan. Sehingga dapat ditarik kesimpulan jika pelanggan sudah merasa puas sehingga perusahaan perlu mempertahankan baik pelayanan, kualitas produk ataupun Sharing kwoledge karyawan terhadap pelanggan, sehingga dari pelanggan akan timbul kesan positif yang menjadikan pelanggan akan tetap loyal terhadap Rumah Batik Danar Hadi.

\section{DAFTAR PUSTAKA}

Alma, Buchari. 2010. Pengantar Bisnis. Penerbit Alfabeta Bandung.

Cahyono. Basuki. Deasy Amboningtyas. 2011. Analisa Kekuatan Strategi Pemasaran Melalui Online Marketing, Offlinemarketing Dan Service Excellent Terhadap Loyalitas Konsumen Pt. Adinatagraha Raya Kaliwungu Dengan Kepuasan Konsumen Sebagai Variabel Intervening. Jurnal Managemen Fakultas Ekonomika Dan Bisnis Universitas Pandanaran.

Griffin, Jill. 2008. Customer Loyalty How To Learn IT, How To Keep If. Mc. Grow.

Halimah, Pengaruh Customer Relationship Management terhadap loyalitas pelanggan Pada PT Bank Riau Kepri Cabang Utama Pekan Baru, Jurnal Studi Administrasi Bisnis Fisip Universitas Riau. Jom FISIP Vol 2 No 2.

Hariyanto, David. Dr Harianto Subagio SE., MM. 2013. Analisa Pengaruh Kualitas Layanan, Brand Image dan Atmosfere Terhadap Loyalitas Pelanggan dengan Kepuasan Konsumen Sebagai Variabel Intervening Konsumen Kedai De Javu Surabaya. Jurnal Manajemen Pemasaran no 1 Vol 12013.

Harynono, Novan. Roony Octavia. 2014. Analisis Pengaruh Citra merek dan Mutu Layanan

Terhadap Kepuasan Konsumen Serta Dampaknya terhadap Loyalitas Konsumen

Hurriyati, Ratih. 2008. Bauran Pemasaran dan Loyalitas Konsumen. Bandung: Penerbit CV. Alfabeta.

Kotler dan Keller. 2007. Manajemen pemasaran Jilid 1 (12nd ed). Jakarta: PT Gelora Aksara Pratama.

Kotler, P., \& Amstrong, G. (2008). Prinsip-Prinsip Pemasaran Jilid 2. Edisi 12. Jakarta: Penerbit Erlangga 
Dinamika Sosial Budaya, Vol 22, No. 1, Juni 2020, pp 45-53

p-ISSN: 1410-9859\& e-ISSN: 2580-8524

http://journals.usm.ac.id/index.php/jdsb

Kottler, P., \& Keller, K. L. (2009). Marketing Management. 13th Ed. New Jersey: Upper Saddle River

Kotler, P dan Keller, K. (2009). Manajemen Pemasaran. Edisi 13. PT. Gelora Aksara Pratama, Jakarta

Kotler, Philip and Kevin Lane Keller. 2009. Manajemen Pemasaran. Edisi 13 Jilid 1. Dialih bahasakan oleh Bob Sabran, MM. Jakarta: Erlangga

Kotler, P., \& Armstrong, G. (2011). Principles of Marketing (14th ed.). New Jersey: Prentice Hall

Kotler, Philip \& Gary Armstrong. 2012. Principles of Marketing, 14th edition. Pearson Education Limited, England

Lombard, M.R dan du Plessis, L. 2012. Customer Relationship Management (CRM) in a South African Service Environment: an Exploratory Study. African Journal of Marketing Management. Vol.4, Pp. 152-165.

Lovelock, Christopher \& Jochen Wirtz. 2011. Services Marketing. Peoples, Technology, Strategy. 7th edition. Pearson Education Limited, England.

Lupipyoadi, Rambat 2009. Manajemen Pemasaran Jasa. Jakarta: Salemba Empat

Maddy, Khairul. Hakikat dan Pengertian Pelayanan Prima. Jakarta; Chama Digital 2009.

Rasyid, H. A. (2017). Pengaruh Kualitas Layanan Dan Pemanfaatan Teknologi Terhadap Kepuasan

Dan Loyalitas Pelanggan Go-Jek. Jurnal Ecodemica, 1(2), 200-214

Ruslan, Rosady. 2005. Manajemen Public Relations dan Media Komunikasi, konsepsi, dan aplikasi, edisi revisi, Jakarta, PT. Raja Grafindo Persada

Schiffman, L.G \& Kanuk, L.L. (2007). Consumer behavior (9th ed.). London: Prentice Hall

Setyobudi, Ismanto dan Daryanto. 2014. Konsumen dan Pelayanan Prima. Yogyakarta: Gava Media
Sheth, Parvatiyar, dan Shainesh. 2002. Customer relationship management: emerging concepts, tools and application. New Delhi: McGraw-Hill Thaichon, P., Lobo, A. and Mitsis, A. (2014), "An empirical model of home internet services quality in Thailand", Asia Pacific Journal of Marketing and Logistics, Vol. 26 Iss 2 pp. 190 $-210$

Tjiptono, Fandy. 2005. Pemasaran Jasa. Malang: Bayu Media Publishing

Tjiptono, Fandydan Gregorius Chandra. 2008. Service Quality Dan Satifiction. Andi Offset.Yogyakarta.

Victor, Christian. Rotinsuru Jopie Jorie. 2015. Pengaruh Customer Relationship Managemen dan Kepercayaan terhadap Kepuasan Serta Dampaknya Terhadap Loyalitas Pada Bank BCA Tbk Di Manado. Jurnal Ekonomi dan Bisnis. Vol 3 No 2 Juni 2015 